\title{
THE EFFECT OF DIVERSIFICATION LEVEL, NUMBER OF SEGMENTS, AND INDUSTRY SECTOR TYPE ON COMPANY PERFORMANCE
}

\author{
Felicia Hokyani, Rizka Indri Arfianti
}

\author{
KWIK KIAN GIE SCHOOL of BUSINESS \\ hokyanifelicia@gmail.com; rizka.indri@kwikkiangie.ac.id
}

Received: November $19^{\text {th }} 2020$

Approved: January $15^{\text {th }} 2021$

\begin{abstract}
The high competition in the business world with many competitors has forced the company to develop its business, one of them by diversification. This study aims to investigate the influence of diversification level, the number of segments, and type of industrial sector on firm performance measured by the excess value. The theory underlying this research is agency theory, which describes the relationship between the company owners with the company management. The number samples of this study are 333 companies from the miscellaneous industry sector, consumer goods sector, and basic industry and chemicals sector listed on the Indonesia Stock Exchange throughout 2017 - 2018. The results showed that data can be pooled for 3 years, all classic assumption tests are fulfilled, and partial regression coefficient test found that variable diversification level and the variable number of segments $>0.05$, then $\mathrm{H}_{0} \mathrm{l}$ and $\mathrm{H}_{0} 2$ rejected, while the type of miscellaneous industry sector and type of consumer goods sector $<0.05$, then $\mathrm{H}_{0} 3$ and $\mathrm{H}_{0} 4$ received. The conclusion showed that variable diversification level and number of segments has not sufficient evidence of a negative effect on excess value, while the type of miscellaneous industry sector and type of consumer goods sector sufficient evidence of a negative effect on excess value.
\end{abstract}

Keywords: Diversification Level, Firm Performance, Industrial Sector, and Number of Segments

\section{Introduction}

In general, financial reports are the results of the accounting process that contain financial data based on Kieso (2016) says that the performance of a company can be seen from the financial statements in the company in one accounting period. According to Salindeho et al (2018), company performance is a description of the financial situation of a company which is analyzed with financial analysis tools, so that the good and bad financial conditions of a company that reflect work performance can be known within a certain period. One of the performance measures can be measured by the Excess Value of Firm (EXVAL), 
which is the difference in the performance of a multi-segment company compared to a single segment company disclosed by Berger and Ofek (1995).

Indonesia is a country with a population that has a very high level of consumption. People are willing to pay more for the desired item which causes business competition is currently very tight and market growth is very fast in today's economy so that companies are indirectly required to always develop and change, with the hope that business excellence can be maintained and value companies can be upgraded.

Diversification is a form of business development by expanding the number of segments in business and geographic ways, expanding existing market share, or developing various types of products. This can be done through various actions, such as: opening new business lines, expanding existing product lines, expanding the area of product marketing, opening branch offices, conducting mergers and acquisitions to increase economies of scale, and other ways described by Rani (2015)

Company size is a scale that can classify the size of the company according to various ways, including total assets, log size, stock market value, and others proposed by Harto (2005). Based on PSAK No. 05 revision 2000, it is mandatory for every company that has various business and geographic segments, each of which has met the criteria for sales, assets, and certain operating income to report these business segments as part of the published financial statements.

Types of Industrial Sectors can provide a description and analysis of company diversification that has not been widely carried out in Indonesia and the development of research models per industry is expected to be able to identify the role generated by the application of diversification in a company.

\section{Literature review}

\section{A. Agency Theory}

Agency theory was first put forward by Jensen and Meckling (1976: 283), explaining agency theory states that there is a relationship between the company owner (principal) and the manager (agent) in carrying out their respective functions and authorities. The principal delegates his authority to the manager to manage the company, with the hope that the principal will get benefits and increase wealth and welfare. Jensen and Meckling (1976: 283) reveal that agency theory will cause a conflict between the principal and where the principal has an interest in entering into a contract with an agent that aims to gain profit and prioritizes personal interests by increasing the company's profitability. The agent has an interest in emphasizing the compensation it gets so that sometimes it is not in the principal's interests.

\section{B. Signalling Theory}

Signal theory was first proposed by Spence (2002: 434-459) in which the owner of the information tries to provide information that can be used by the recipient of the information. Furthermore, the recipient will adjust their behavior according to their understanding of the signal and the theory of corporate signal disclosure will later influence investors in making decisions developed by Wolk et al (2003).

\section{Company Performance}

Company performance is a description of the level of achievement of the implementation of company activity in realizing the goals, objectives, mission, and vision 
of the organization as stated in the strategic planning of a company, so that performance is the ability to do work as measured by work results. Berger and Ofek (1995: 39) reveal that EXVAL is the difference in the performance of a multi-segment company with a single segment company. If the EXVAL value of a company that is diversifying is positive, then the company that is diversifying will have a better performance than a single segment company. If the EXVAL value of a company that diversifies is negative, then the diversified company will have lower performance than a single segment company.

\section{Framework and Hypotheses}

\section{The effect of diversification on company performance}

The level of company diversification, as measured by the Herfindahl Index, shows how concentrated a company is in its business segment. The level of company diversification the more diversified the lower the company's performance. Because there is a conflict of interest on the part of the manager who does not pay attention to the negative net present value but only prioritizes the incentives and rewards that you want to get so that the motive for diversification will reduce the company's performance. This is in line with the research of Satoto (2009), Chandra and Triyani (2015).

\section{$H_{a 1}$ : The level of diversification has a negative effect on company performance}

2. The effect of the number of business segments on company performance

A multi-segment company has lower performance than a single segment company. This is because the manager's conflict of interest can also lead to a decrease in excess value. Managers open many new business segments only for short-term interests, namely to increase turnover for the sake of getting incentives. However, the long-term effects were ignored. Moreover, if one of the business segments opened has a loss, then cross subsidies must be carried out from the profitable segment to the unprofitable segment, which results in a decrease in excess value. This is in line with the research of Harto (2007), Amyulianthy and Sari (2013), and Setionoputri et al (2007).

$\mathrm{H}_{\mathrm{a} 2}$ : The number of business segments has a negative effect on company performance.

\section{The influence of various industrial sectors on company performance}

Multi-segment companies have a lower excess value than single segment companies, where the industrial sector against excess value is sorted based on the multi-segment proportion of each industrial sector being the sample of this study.

Proportion of Multi-Segment Industrial Sector

\begin{tabular}{|l|c|c|c|c|}
\hline \multicolumn{1}{|c|}{ Sector } & $\begin{array}{c}\text { Multi- } \\
\text { segment }\end{array}$ & $\begin{array}{c}\text { Single- } \\
\text { segment }\end{array}$ & Amount & $\begin{array}{c}\text { Proportion } \\
\text { MS }\end{array}$ \\
\hline Various Industries & 21 & 5 & 26 & $80,77 \%$ \\
\hline Consumer Goods & 27 & 7 & 34 & $79,41 \%$ \\
\hline Basic Industry and Chemicals & 37 & 14 & 51 & $72,55 \%$ \\
\hline Total & 85 & 26 & 111 & $76,58 \%$ \\
\hline
\end{tabular}

Company performance is a measure of the excess value of a multi-segment company against a single segment by controlling the industrial effect, the goal is to measure the influence of the industrial sector on excess value sorted by the largest proportion of 
multi-segment segments from each industrial sector, namely the various industrial sectors with the largest multi-segment proportion have the performance companies that are lower than other industrial sectors (consumer goods sector, basic industrial sector and chemicals, and infrastructure and utility sector). This is in line with the research of Harto (2007), Chandra and Triyani (2015), Setionoputri et al (2007).

$H_{a 3}$ : Various industrial sectors have a negative effect on company performance.

4. The influence of the consumer goods sector on company performance

The industrial sector towards excess value is sorted based on the largest multisegment segment proportion of each industrial sector, so the consumer goods sector is a multi-segment company with the second largest proportion. So it can be concluded that the consumer goods sector becomes a variable 2 on excess value and the type of consumer goods sector has a negative effect on excess value. This is in line with the research of Harto (2007), Chandra and Triyani (2015), Setionoputri et al (2007).

$H_{a 4}$ : The consumer goods sector has a negative effect on company performance.

Framework

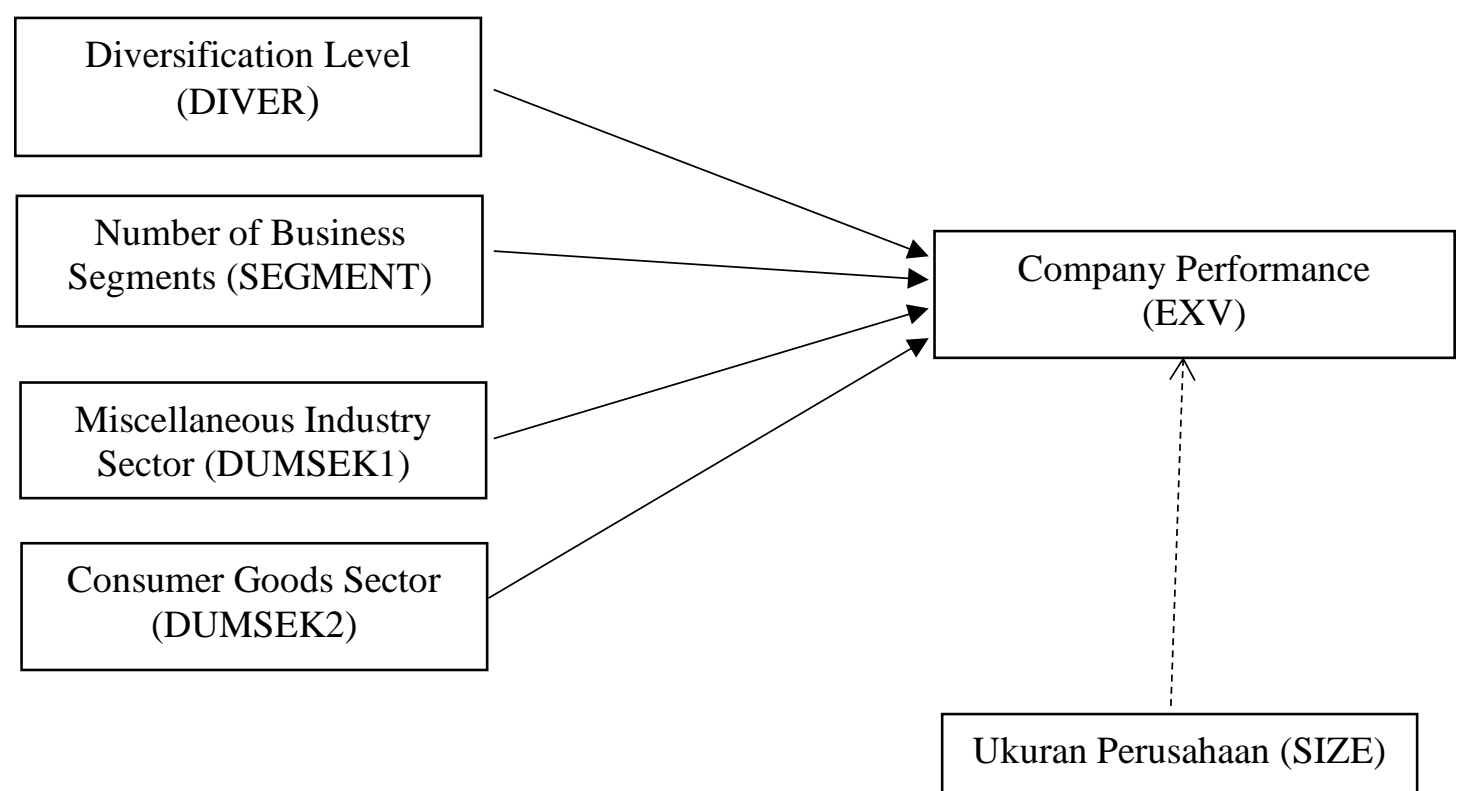

\section{Methodology}

This research was conducted on manufacturing companies (various industrial sectors, consumer goods industry sector, and basic and chemical industry sectors) which are listed on the Indonesia Stock Exchange (IDX) which have published financial reports consecutively during the 2016 - 2018 period and data closing price for manufacturing companies in 2016 2018 which was obtained from the website www.finance.yahoo.com.

\section{A. Research Variabel}

\section{Dependent Variable}

In this study, the dependent variable used is company performance as measured by the Excess Value of Firm (EXV), which is a performance measure used in examining the 
performance comparison between single-segment companies and companies that diversify (multi-segment). According to Berger \& Ofek (1995), company performance, which is proxied by excess value, is formulated as follows:

$E X V=\operatorname{In}\left(\frac{M C}{I V_{i, t}}\right)$

$I V_{i, t}=\sum_{i=1}^{n}$ Segsales $x$ Ind $\left(\frac{\text { Market }}{\text { Sales }}\right) j$

Explanation:

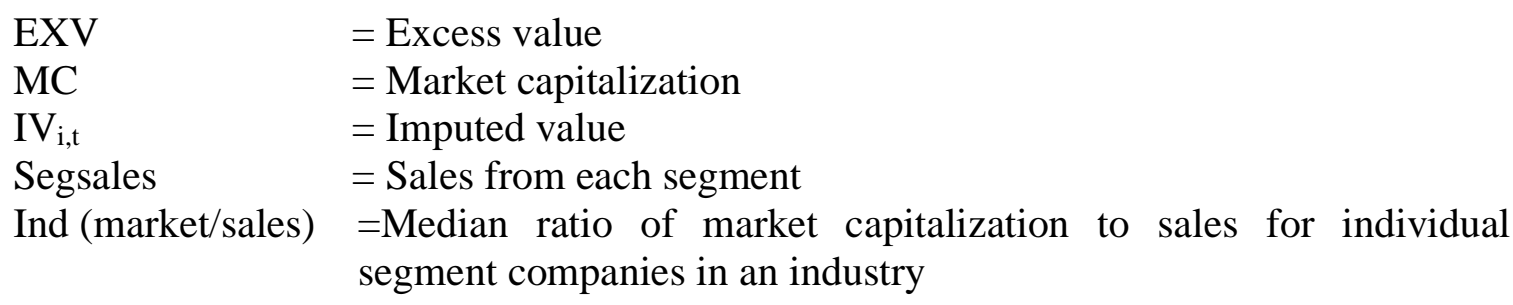

Market capitalization is the market value of equity shares plus book value of liabilities

The formula is:

$M C=M V S+B V L$

Explanation:

MC = Market Capitalization

MVS = Market Value of Equity Shares

BVL $\quad=$ Book Value of Liability

Market value of equity shares can be calculated from the multiplication of the closing price and the number of shares outstanding, using the formula:

$M V S=C P x N O S O$

Explanation:

MVS $=$ Market Value of Equity Shares

$\mathrm{CP} \quad=$ Closing Price

NOSO $=$ Number of shares outstanding

\section{Independent Variable}

In this study, researchers used three independent variables, namely:

a. Diversification Level

The level of diversification as measured by the Herfindahl Index. The Herfindahl index introduced by Herfindahl (1950) is used to measure diversification because it can measure the distribution of market control or the calculation of market concentration in the industry.

Harto (2007) the level of diversification as proxied by the Herfindahl index is formulated as follows:

$H=\frac{\sum_{i=1}^{n} \text { Segsales }^{2}}{\left(\sum_{i=1}^{n} \text { Sales }^{2}\right.}$

Explanation:

$\mathrm{H}=$ Herfindahl index 


$$
\begin{array}{ll}
\text { Segsales } & =\text { Sales from each segment } \\
\text { Sales } & =\text { Total Sales }
\end{array}
$$

b. Number of Business Segments

The number of business segments is measured using a dummy variable which is used to control the effect of the number of business segments the company has. The segment dummy variable consists of 2 categories, namely given a value of 1 if the company has more than one business segment (multi-segment) and given a value of 0 if the company only has a single sector (single-segment).

c. Type of Industry Sector

The type of industrial sector measured using a dummy variable which is used to control the effect of the number of business segments the company has. Types of industrial sectors are proxied by the various industrial sectors, the consumer goods sector, the basic industrial sector, and chemicals.

According to Setionoputri et al (2007), the sector dummy variable 1 (DUMSEK 1) for various industrial sectors is given a value of 1 , while 0 for other industrial sectors. This is because the various industrial sectors have the first largest multisegment proportion. The sector 2 dummy variable (DUMSEK 2) for the consumer goods sector is given a value of 1 , while 0 for other industrial sectors. This is because the various industrial sectors have the second-largest multi-segment proportion.

\section{Contro Variable}

The control variable is the size of the company as measured by the log-normal value of total assets owned by the company Harto (2007). The company size is formulated as follows:

$S I Z E=\ln (T A)$

Explanation:

SIZE = Company size

Ln $\quad=$ Log natural

TA $\quad=$ Total assets

\section{B. Data Collection and Sampling Techniques}

Researchers use observation techniques and use secondary data. The data observed are independent auditors' reports and annual financial reports of manufacturing companies (various industries, consumer goods industry, and basic and chemical industries) listed on the Indonesia Stock Exchange (IDX) for the period 2016 - 2018.

For sampling, researchers used a non-probabilistic sampling technique with a purposive sampling approach in which certain criteria were used to obtain a representative sample. Obtained 111 companies during the study period of 3 years to obtain 333 data samples.

\section{Data Analysis Techniques}

The analysis was carried out in analyzing the data using the SPSS 20.0 application. The steps in conducting data analysis are as follows:

\section{Pooling Test}


The pooling test is carried out to determine whether there are differences in the intercept, slope, or both between the existing regression equations. This test is performed using dummy variables. If the significant dummy value is greater than 0.05 , data pooling can be performed. The following is the pooling test equation for each research model:

$$
\begin{aligned}
& \text { EXV }=\beta_{0}+\beta_{1} \text { DIVER }+\beta_{2} \text { SIZE }+\beta_{3} \text { DUMSEG }+\beta_{4} \text { DUMSEK } 1+\beta_{5} \text { DUMSEK } 2+ \\
& \beta_{6} \mathrm{DT}_{1}+\beta_{7} \mathrm{DT}_{2}+\beta_{8} \mathrm{DT}_{1} \text { DIVER }+\beta_{9} \mathrm{DT}_{1} \text { SIZE }+\beta_{10} \mathrm{DT}_{1} \mathrm{DUMSEG}+\beta_{11} \\
& \mathrm{DT}_{1} \text { DUMSEK } 1+\beta_{12} \text { DT DUMSEK } 2+\beta_{13} \mathrm{DT}_{2} \text { DIVER }+\beta_{14} \mathrm{DT}_{2} \text { SIZE }+ \\
& \beta_{15} \mathrm{DT}_{2} \text { DUMSEG }+\beta_{16} \mathrm{DT}_{2} \text { DUMSEK } 1+\beta_{17} \mathrm{DT}_{2} \text { DUMSEK } 2+\varepsilon_{\mathrm{i}, \mathrm{t}}(7)
\end{aligned}
$$

\begin{tabular}{|c|c|}
\hline $\mathrm{p}$ & \\
\hline$E X V A L$ & : Company performance as measured by excess value \\
\hline$\beta_{0}$ & : Constant \\
\hline$\beta_{1}-\beta_{17}$ & : Regression coefficient \\
\hline DIVER & The level of company diversification as measured by the Herfindahl \\
\hline ndex & \\
\hline IZE & : Company size \\
\hline DUMSEG & $\begin{array}{l}\text { : Dummy variable }(1=\text { various segment company and } 0=\text { single } \\
\text { segment company) }\end{array}$ \\
\hline $\begin{array}{l}\text { DUMSEK1 } \\
\text { industrial sec }\end{array}$ & $\begin{array}{l}\text { : Dummy variable }(1=\text { various industrial sectors and } 0=\text { other } \\
\text { or) }\end{array}$ \\
\hline $\begin{array}{l}\text { UMSEK } 2 \\
\text { ector) }\end{array}$ & : Dummy variable $(1=$ consumer goods sector dan $0=$ other industrial \\
\hline $\mathrm{DT}_{1}$ & $\begin{array}{l}\text { : Dummy variable for the year }(1=\text { company data in } 2018,0= \\
\text { company data in } 2017,2016)\end{array}$ \\
\hline $\mathrm{DT}_{2}$ & $\begin{array}{l}\text { : Dummy variable for the year }(1=\text { company data in } 2017,0= \\
\text { company data in } 2018,2016)\end{array}$ \\
\hline & \\
\hline
\end{tabular}

\section{Descriptive Statistics}

Descriptive statistics according to Ghozali (2013: 19) are data descriptions or descriptions seen from the average value, standard deviation, variance, maximum value, minimum value, sum, and range. Descriptive statistical data can be obtained with the help of the SPSS program. Researchers used SPSS version 20.0 to perform descriptive statistical analysis.

\section{Classic Assumption Test}

In this study, the classical assumption test consisted of normality test, multicollinearity test, autocorrelation test, and heteroscedasticity test.

\section{Multiple Regression Analysis}

Ghozali (2013: 93), multiple regression analysis aims to model the relationship between the dependent variable and the independent variable with more than one independent variable. The model used in multiple regression is as follows:

$$
\begin{aligned}
& \text { EXV }=\beta_{0}+\beta_{1} \text { DIVER }+\beta_{2} \text { SIZE }+\beta_{3} \text { DUMSEG }+\beta_{4} \text { DUMSEK } 1+\beta_{5} \text { DUMSEK } 2 \\
& +\varepsilon_{\mathrm{i}, \mathrm{t}}
\end{aligned}
$$

Explanation: 


\begin{tabular}{|c|c|}
\hline EXVAL & : Company performance as measured by excess value \\
\hline$\beta_{0}$ & : Constant \\
\hline$\beta_{1}-\beta_{5}$ & : Regression coefficient \\
\hline DIVER & : The level of company diversification as measured by the Herfindahl index \\
\hline SIZE & : Company size \\
\hline $\begin{array}{l}\text { DUMSEG } \\
\text { company) }\end{array}$ & : Dummy variable $(1=$ various segment company and $0=$ single segment \\
\hline DUMSEK1 & : Variabel dummy $(1=$ various industrial sectors and $0=$ other industrial sector $)$ \\
\hline DUMSEK2 & : Variabel dummy $(1=$ consumer goods sector dan $0=$ other industrial sector $)$ \\
\hline & Error \\
\hline
\end{tabular}

\section{Result}

\section{A. Descriptive Analysis}

Following are the results of the descriptive analysis test:

Descriptive Analysis Test Results

\begin{tabular}{|l|c|l|l|l|l|}
\hline \multicolumn{1}{|c|}{ Variable } & $\mathrm{N}$ & Minimum & Maximum & \multicolumn{1}{c|}{ Mean } & Std. Deviation \\
\hline EXV & 333 & $-2,1425$ & 8,1332 & 0,257646 & 1,2235959 \\
\hline DIVER & 333 & 0,26 & 1 & 0,707243 & 0,2526725 \\
\hline SIZE & 333 & 24,4199 & 34,8292 & 28,369477 & 1,6590128 \\
\hline DUMSEG & 333 & 0 & 1 & 0,77 & 0,424 \\
\hline DUMSEK 1 & 333 & 0 & 1 & 0,23 & 0,424 \\
\hline DUMSEK 2 & 333 & 0 & 1 & 0,31 & 0,462 \\
\hline
\end{tabular}

Based on the results of the descriptive analysis test above, it can be seen that there were 333 companies observed for the 2016 - 2018 period

The company performance variable (EXV) has an average value of 0.257646 . the lowest value of company performance variable (EXV) of -2.1425 owned by PT Alaska Industrindo Tbk (ALKA), in 2016 which means that the resulting performance is the lowest compared to other sample companies, while the highest value of company performance variable (EXV) is 8.1332 owned by PT Jakarta Kyoei Steel Work LTD Tbk (JKSW), in 2018 which means that the resulting performance is the highest compared to other sample companies. The standard deviation of company performance variables (EXV) of 1.2235959 is greater than the mean of 0.257646 , which means that there are high data deviations so that indicates that the data on the company performance variable (EXV) is not good

The variable level of diversification (DIVER) has an average value of 0.707243 which is more inclined to number 1 than number 0 , this shows that the average manufacturing companies in various industrial sectors, consumer goods sectors, and basic industrial and chemical sectors have to diversify concentrated. The lowest value of the diversification level variable (DIVER) is 0.2600 owned by PT Kalbe Farma Tbk (KLBF), in 2016, this means diversification is not concentrated. Meanwhile, the highest value of the diversification level variable (DIVER) is 1,000 owned by each manufacturing company that does not diversify (single-segment). The standard deviation of the diversification level variable (DIVER) is 0.2526725 smaller than the mean of 0.707243 , which means that there is no high data deviation so it indicates that the data on the diversification level variable (DIVER) is good. 
The firm size variable (SIZE) has an average value of 28.369477. The lowest value of the company size variable (SIZE) was 24.4199 owned by PT Siwani Makmur Tbk (SIMA) in 2016 with total assets of 40,312,397,678, while PT Inti Keramik Alam Asri Industri Tbk (IKAI) in 2018 with total assets in the amount of 1,337,016,109,000,000. The standard deviation of the firm size variable (SIZE) is 1.6590128 which is smaller than the mean of 28.369477 which means there is no high data deviation so it indicates that the data on the firm size variable (SIZE) is good.

The number of segments variable (DUMSEG) has an average value of 0.77 which is more inclined to number 1 than number 0 , this shows that the average manufacturing company for various industrial sectors, consumer goods sectors, and basic industrial and chemical sectors has several segments. more than one. The lowest value of the number of segments variable (DUMSEG) is 0 owned by all non-diversified manufacturing companies (single-segment), while the highest value for the number of segments variable (DUMSEG) is 1 owned by all diversified manufacturing companies (multi-segment). ). The standard deviation of the number of segments variable (DUMSEG) is 0.424 which is smaller than the mean of 0.77 , which means that there is no high data deviation so it indicates that the data on the variable number of segments (DUMSEG) is good.

The miscellaneous industry sector variable (DUMSEK 1) has an average of 0.23 . The lowest value of the various industrial sector variables (DUMSEK 1) is 0 owned by all manufacturing companies involved in the basic industry and chemical or consumer goods sectors, while the highest value of the various industrial sector variables (DUMSEK 1) is 1 owned by all manufacturing companies, who are involved in various industrial sectors. The standard deviation of the various industrial sector variables (DUMSEK 1) is 0.424 which is greater than the mean of 0.23 which means that there are high data deviations so that it indicates that the data on the various industry sectors variables (DUMSEK 1) is good.

The consumer goods sector variable (DUMSEK 2) has an average of 0.31 . The lowest value of the consumer goods sector variable (DUMSEK 2) is 0 owned by all manufacturing companies involved in the basic and chemical industry or various industrial sectors, while the highest value for the consumer goods sector variable (DUMSEK 2) is 1 owned by all manufacturing companies engaged in the consumer goods sector. The standard deviation of the consumer goods sector variable (DUMSEK 2) is 0.462 which is greater than the mean of 0.31 which means that there is a high data deviation so which indicates that the data on the consumer goods sector variable (DUMSEK 2) is good.

\section{B. Research Results}

\section{Pooling Tests}

After the pooling test, the results of the dummy variable (DT) and all their interactions with the independent variables (DIVER, SIZE, DUMSEG, DUMSEK1, and DUMSEK2) have a significant value above 0.05 , so it can be concluded that there is no difference in diagonal lines throughout the year and sector, which means the data can be pooled for 3 years.

\section{Classic Assumption Test}

\section{Classic Assumption Test Result}

\begin{tabular}{|l|c|c|c|c|c|}
\hline \multirow{2}{*}{ Variable } & \multicolumn{5}{|c|}{ Type of Test } \\
\cline { 2 - 6 } & Normality & Multicollinearity & VIF & Autocorrelation & Heteroscedasticity \\
\hline DIVER & 0,0000 & 0,571 & 1,751 & 2,003 & 0,987 \\
\hline
\end{tabular}




\begin{tabular}{|c|c|c|c|c|c|}
\hline \multirow{2}{*}{ Variable } & \multicolumn{5}{|c|}{ Type of Test } \\
\hline & Normality & Multicollinearity & VIF & Autocorrelation & Heteroscedasticity \\
\hline SIZE & & 0,951 & 1,051 & & 0,348 \\
\hline DUMSEG & & 0,581 & 1,722 & & 0,812 \\
\hline DUMSEK 1 & & 0,857 & 1,167 & & 0,119 \\
\hline DUMSEK 2 & & 0,848 & 1,179 & & 0,101 \\
\hline
\end{tabular}

Based on the results of the classical assumption test (normality), it can be seen that the significance value is 0.0000 (obtained through the Kolmogorov Smirnov onesample test). This value is smaller than 0.05 , so Ho rejects, which means that the residual data is not normally distributed. However, according to Bowerman and O'Connell (1979: 286) states that if the sample size is $\geq 30$, then the entire population is said to be normally distributed. Because this study using 333 samples, it can be concluded that the residual data is said to have a normal distribution.

Based on the results of the classical assumption test (multicollinearity), it can be seen that the DIVER, SIZE, DUMSEG, DUMSEK 1, and DUMSEK 2 Toll values have tolerance values respectively $0.571,0.951,0.581,0.857,0.848$. Meanwhile, the VIF values for the DIVER, SIZE, DUMSEG, DUMSEK 1, and DUMSEK 2 Tolls have VIF values of $1.751,1.051,1.722,1.167$, and 1,179, respectively. All tolerance values obtained are greater than 0.10 and VIF values are below 10. So accept Ho, so it can be concluded that there is no multicollinearity in the study or other words, there is no correlation between the independent (free) variables.

Based on the results of the classic assumption test (autocorrelation), it can be seen that the $\mathrm{d}$ value is 2,003 (obtained through the Durbin Watson test). This study uses 333 samples and 5 independent variables so that the $\mathrm{dU}$ value is 1.8440 and the value (4$\mathrm{dU})$ is 2.156 , which means it can be concluded that there is no autocorrelation $(1.8440$ $<2.003<2.156)$.

Based on the results of the classic assumption test (heteroscedasticity), it can be seen that the significant values of DIVER, SIZE, DUMSEG, DUMSEK1, and DUMSEK2 have significant values respectively $0.987,0.348,0.812,0.119,0.101$. All of these values are greater than 0.05 , so Ho rejects and means that there is no heteroscedasticity.

\section{Multiple Regression Analysis}

\section{Regression Analysis Results}

\begin{tabular}{|c|c|c|c|c|c|}
\hline \multirow[b]{2}{*}{ Variable } & F Test & \multicolumn{3}{|c|}{ t Test } & \multirow[b]{2}{*}{ r square } \\
\hline & $\begin{array}{c}\text { Sig. } \\
\text { (ANOVA) }\end{array}$ & B & $\begin{array}{l}\text { Sig. (2- } \\
\text { tailed) }\end{array}$ & $\begin{array}{l}\text { Sig. (1- } \\
\text { tailed) }\end{array}$ & \\
\hline (Constant) & \multirow{6}{*}{0,00100} & $-3,184$ & & & \multirow{6}{*}{0,06} \\
\hline DIVER & & $-0,178$ & 0,606 & 0,303 & \\
\hline SIZE & & 0,137 & 0,001 & 0,0005 & \\
\hline DUMSEG & & $-0,138$ & 0,496 & 0,248 & \\
\hline DUMSEK 1 & & $-0,404$ & 0,016 & 0,008 & \\
\hline DUMSEK 2 & & $-0,387$ & 0,013 & 0,0065 & \\
\hline
\end{tabular}

The multiple linear regression analysis test obtained the following model: 
EXV $=-3.184-0.178$ DIVER +0.137 SIZE -0.138 DUMSEG - 0.404 DUMSEK1 0.387 DUMSEK2

The simultaneous significance test (Test F) can be seen that the significance value is $0.00100<0.05$, therefore the value is less than 0.05 , which means that the regression model can be used to show the influence of the independent variable on the dependent variable, so it can be concluded that the DIVER, SIZE, DUMSEG, DUMSEK 1 variables, and DUMSEK 2 together (simultaneously) affect the dependent variable, namely EXV.

The partial regression coefficient test (t-test) can be seen that the correlation in each research variable: The diversification level variable (DIVER) has a sig-t value (onetailed) of $0.303>0.05$, meaning that Ho1 does not reject Ha1. This shows that the level of diversification as measured by the Herfindahl Index is not sufficient evidence of an effect on company performance as measured by excess value. The coefficient value for the diversification level variable (DIVER) is -0.178 (negative), indicating that the diversification level does not have a negative effect on company performance as measured by excess value.

The variable number of segments (DUMSEG) has a sig-t value (one-tailed) of $0.248>0.05$. not reject $\mathrm{Ho} 2$ reject Ha2. This shows that the number of segments is not sufficient evidence of an effect on the company's performance as measured by excess value. The coefficient value for the number of segments variable (DUMSEG) is -0.138 (negative), indicating that the number of segments has no negative effect on company performance as measured by excess value.

The miscellaneous industry sector variable (DUMSEK 1) has a sig-t (one-tailed) value of $0.008<0.05$. reject $\mathrm{Ho} 3$ not reject Ha3. This shows that various industrial sectors have sufficient evidence of affecting company performance as measured by excess value. The coefficient value for various industrial sector variables (DUMSEK 1) is -0.404 (negative) indicating that various industrial sectors have a negative effect on company performance as measured by excess value.

The consumer goods sector variable (DUMSEK 2) has a sig-t (one-tailed) value of $0.0065<0.05$, Ho4 does not reject Ha4. This shows that the consumer goods sector is sufficiently evident to affect company performance as measured by excess value. The coefficient value for the consumer goods sector variable (DUMSEK 2) is -0.387 (negative) indicating that the consumer goods sector has a negative effect on company performance as measured by excess value.

\section{Discussion}

Based on the research results above, the researcher will discuss the meaning of the research results obtained as follows:

\section{The influence of level of diversification on company performance}

The level of diversification (DIVER) is not sufficient evidence of a negative effect on company performance as measured by excess value. This result is not following the initial hypothesis which states that the level of diversification (DIVER) has a negative effect on company performance. However, in this study the level of diversification (DIVER) does not affect company performance, this is because according to Setionoputri et al. (2007) there is a lack of strong people's views that the level of diversification (DIVER) of a company calculated from the Herfindahl index can affect company performance. A negative direction can be interpreted that companies that diversify will spend a lot of costs 
that are not proportional to the results obtained so that there will be losses in the opened segment of the company and the company's overall performance will decline.

This can be seen from the research data that the higher the diversification, the higher the company's performance in 2018 PT Alam Karya Unggul Tbk (AKKU) has a diversification level value of 0.934 so that the company's performance value is 1.530832 . In 2017 PT Aneka Gas Industri Tbk (AGII) had a diversification level of 0.823 so that the company's performance value was 0.783265. In 2016 PT Eterindo Wahanatama Tbk (ETWA) had a diversification level of 0.900 so that the company's performance value was 1.213715. There is also research data that the lower the diversification, the lower the company's performance in 2018 PT Alkindo Naratama Tbk (ALDO) has a diversification level value of 0.349 so that the company's performance value is -1.89855 . In 2017 PT Chitose International Tbk (CINT) had a diversification level of 0.307 so that the company's performance value was -1.12878 . But there is also research data that the higher the diversification, the lower the company's performance in 2018 PT Alaska Industrindo Tbk (ALKA) has a diversification level value of 0.943 so that the company's performance value is -0.7622 . In 2017, PT Alaska Industrindo Tbk (ALKA) had a diversification level of 0.911, so the company's performance value was -1.8032. In 2016 PT Alaska Industrindo Tbk (ALKA) had a diversification level of 0.885 so that the company's performance value was -2.1425 . Due to a large number of variations in the data in the study sample, this means that the level of diversification does not affect company performance.

The results of this study are in line with the research of Harto (2007), Setionoputri et al (2007) which states that the level of diversification (DIVER) measured using the Herfindahl index shows insignificant results or insufficient evidence of affecting company performance.

\section{The influence of the number of segments on company performance}

The number of segments (DUMSEG) is not sufficient evidence of a negative effect on company performance. This result is not following the initial hypothesis which states that the number of segments (DUMSEG) has a negative effect on company performance. The number of segments is a dummy variable that is used to control the effect of the number of business segments of the company so that the decision to open multiple segments, in the end, becomes inappropriate because managers only focus on short-term interests without paying attention to long-term consequences for the company. Besides, the existence of cross-subsidies from one segment (profit) to another (loss) causes a decline in company performance. However, in this study, the number of segments (DUMSEG) does not affect company performance because according to Setionoputri et al (2007), it is not strong enough, the view of people that the number of segments (DUMSEG) can affect company performance. The negative direction can be interpreted that multi-segment companies have lower company performance than single segment companies

This can be seen from the research data that the higher the number of segments, the higher the company's performance in 2018 PT Jakarta Kyoei Steel Work LTD Tbk (JKSW) is a multi-segment so that it has a company performance value of 8.133197. In 2017, PT Mulia Industrindo Tbk (MLIA) is a multi-segment company so that it has a company performance value of 4.606317. In 2016, PT Mulia Industrindo Tbk (MLIA) is a multi-segment company so that it has a company performance value of 4,393484 . There is also research data that the lower the number of segments, the lower the company's performance in 2018 PT Cahaya Kalbar Tbk (CEKA) is a single segment so that it has a company performance value of -1.73082 . In 2017 PT Cahaya Kalbar Tbk (CEKA) was a single segment so that it had a company performance value of -1.7053. In 2016 PT Lionmesh Prima Tbk (LMSH) was a single segment so that it had a company performance 
value of -1.79291 . There is also research data that the higher the number of segments, the lower the company's performance in 2018 PT Alkindo Naratama Tbk (ALDO) is a multisegment so that the company's performance value is -1.8986. In 2017, PT Alaska Industrindo Tbk (ALKA) was a multi-segment company so that the company's performance value was -1.8032. In 2016 PT Alaska Industrindo Tbk (ALKA) was a multisegment company so that the company's performance value was -2.1425 . Due to a large number of variations in the data in the study sample, this means that the number of segments does not affect company performance.

This is in line with the research of Amyulianthy and Sari (2013), and Sumendap et al. (2018) which states that the number of segments in the company's diversification strategy does not have a significant effect on company performance

\section{The influence of various industrial sectors on company performance}

The miscellaneous industry sector (DUMSEK 1) is sufficient evidence of a negative effect on company performance. This is following the initial hypothesis which states that various industrial sectors (DUMSEK 1) have a negative effect on company performance.

According to Harto (2007) states that the various industrial sectors with the largest multi-segment proportion have lower company performance than other industrial sectors (consumer goods sector, basic industrial sector and chemical sector, and infrastructure and utility sector), due to the proportion of various industrial sectors with a proportion the largest multi-segment companies have lower company performance than other industrial sectors. So it can be concluded that various industrial sectors have a significant negative effect on company performance. This can be due to the hasty opening of the segment and its management that is not optimal. Another possible reason is that the economic condition of various industrial sectors is in a declining condition so that the performance of the companies in it has decreased.

This can be seen from the research data that sales variations in various industrial sector companies cause the company's performance to be lower. For example, in 2018 PT Ricky Putra Globalindo Tbk (RICY) is a diverse industry sector, with variations in sales, namely manufacturing of underwear and outerwear, trading, and manufacturing of yarn which causes a low company performance value of -0.92209. In 2017, PT Ricky Putra Globalindo Tbk (RICY) is a diverse industry sector, with variations in sales, namely manufacturing of underwear and outerwear, trading, and manufacturing of yarn which causes a low company performance value of -0.83622. In 2016 PT Indospring Tbk (INDS) is a sector of various industries, with variations in sales, are the spare part industry, and the rolling mill industry which causes the company's performance value of -0.79511

This is in line with the research, Chandra, and Triyani (2015) who examined the effect of the type of industrial sector on company performance, and the results show that the type of industrial sector has a significant negative effect on company performance.

\section{The influence of the consumer goods sectors on company performance}

The consumer goods sector (DUMSEK 2) is sufficient evidence of a negative effect on company performance. This is following the initial hypothesis which states that the consumer goods sector (DUMSEK 2) has a negative effect on company performance.

According to Harto (2007) states that multi-segment companies with the second largest proportion are found in consumer goods. Therefore, the consumer goods sector with the largest multi-segment proportion has lower company performance than other industrial sectors (basic industry sector and chemical sector, and the infrastructure and utilities sector), because the proportion of various industrial sectors with the largest multi-segment 
proportion has the best company performance. Lower than other industrial sectors. So it can be concluded that the type of consumer goods sector has a negative effect on excess value. This could be due to the hasty opening of the segment and its not optimal management. Another possible reason is that the economy of the consumer goods sector is declining so that the performance of the companies in it is also decreasing.

This can be seen from the research data that sales variations in the consumer goods sector companies cause the company's performance to be lower. For example, in 2018 PT Chitose International Tbk (CINT) is a consumer goods sector, with variations in sales, namely folding chairs, restaurant banquets, office equipment, education, hospitals, and others which cause a low company performance value of -1.10844 . In 2017, PT Chitose International Tbk (CINT) is a consumer goods sector, with variations in sales, namely folding chairs, restaurant banquets, office equipment, education, hospitals, and others which cause a low company performance value of -1.12878. In 2016 PT Cahaya Kalbar Tbk (CEKA) is a consumer goods sector, has a variety of sales is the vegetable oil which causes a low company performance value of -1.60654 ,

This is in line with the research, Chandra, and Triyani (2015) who examined the effect of the type of industrial sector on company performance, and the results showed that the type of industrial sector had a significant negative effect on company performance.

\section{Conclusion}

Based on the results of the analysis carried out in this study, the conclusions that can be drawn to answer the existing problems are:

There is insufficient evidence that the level of diversification and the number of segments have a negative effect on company performance. Meanwhile, various industrial sectors and the consumer goods sector proved to have a negative effect on company performance.

\section{References}

Amyulianthy, R., \& Nuraini, Sari. (2013), "Pengaruh Diversifikasi Terhadap Kinerja Perusahaan", Binus Business Review, Vol.4, no.1, pp.215-230.

Ariani, M. S. (2019), "Pengaruh Strategi Diversifikasi, Intellectual Capital Dan Karakteristik Perusahaan Terhadap Kinerja Perusahaan Di Indonesia", Jurnal Informasi, Perpajakan, Akuntansi Dan Keuangan Publik, Vol.14, no.1, p.37.

Berger, P. G., \& Eli, O. (1995), “Diversification's Effect on Firm Value”, Journal of Financial Economics, Vol.37, pp.39-65.

Bowerman, B. L., O’Connell, R. T., \& Murphree, E. S. (1979), Business Statistics in Practice, Edisi 7, New York: McGraw-Hill/Irwin.

Chandra, D., \& Triyani, Y. (2015), "Pengaruh Level Diversifikasi, Leverage, Return On Asset, Umur Perusahaan, Dan Sektor Industri Terhadap Nilai Perusahaan Yang Terdaftar Di

BEI Periode 2009-2011", Jurnal Akuntansi Manajemen, Vol.4, no.2, pp.66-84.

Cooper, D. R., \& Schindler, P. S. (2013), Business Research Methods, Edisi 12, New York: McGraw-Hill.

Ghozali, I. (2013), Aplikasi Analisis Multivariette Dengan Program IBM SPSS 23, Edisi 8, Semarang: Badan Penerbit Universitas Diponegoro.

Gujarati, D., \& Dawn, P. (2009), Basic Econometrics, Edisi 4, New York: McGraw-Hill.

Harto, P. (2007), "Kebijakan Diversifikasi Perusahaan Dan Pengaruhnya Terhadap Kinerja: Studi Empiris Pada Perusahaan Publik Di Indonesia”, SNA VIII Solo, pp.297-307.

Ikatan Akuntan Indonesia (2014), Standar Akuntansi Keuangan, Jakarta: Salemba Empat. 
Jensen, M. C., \& William, H. M. (1976), "Theory of The Firm: Managerial Behavior, Agency Cost and Ownership Structure", Journal of Financial Economic, Vol.3, No.4, pp.1-75.

Kieso, D. E., Weygandt, J. J., \& Warfield, T. D. (2016), Intermediate Accounting, Edisi 16, John Wiley and Sons, Inc.

Lucyanda, J., \& Wardhani, R. H. K. (2017), "Pengaruh Diversifikasi Dan Karakteristik Perusahaan Terhadap Kinerja Perusahaan”, Jurnal Riset Akuntansi dan Keuangan.

Rani, P. (2015). "Peran Kepemilikan Manajerial Dalam Memoderasi Pengaruh Strategi Diversifikasi Terhadap Kinerja Perusahaan”, Jurnal Akuntansi dan Keuangan, Vol.4, no.2, pp.162-82.

Rudolfs, D. W., \& Yeschrina, M. (2015), “Dampak Leverage Kepemilikian Institusional Dan Ukuran Perusahaan Terhadap Kinerja Perusahaan Pada Perusahaan Manufaktur Periode 2011-2015", Jurnal Riset Akuntansi dan Keuangan, Vol.13, no.1, pp.1-16.

Salindeho, A. O., Ivonne, S. S., \& Joubert, B. M. (2018), "Pengaruh Diversifikasi Usaha Terhadap Kinerja Keuangan Dan Return Saham Study Kasus Pada Perusahaan Manufaktur Automotive and Effect of Business Diversification of Financial Performance and Return Stock Case Stock in Automotive and Component Manufacturing”, Jurnal Riset Akuntansi dan Keuangan, Vol.6, no.3, pp.1078-87.

Sari, I. (2015), "Pengaruh Strategi Diversifikasi Dan Karakteristik Perusahaan Terhadap Kinerja Perusahaan", Media Riset Akuntansi, Vol.4, no.2, pp.1-23.

Sari, I. A., Wiratno, A., \& Suyono, E. (2014), "Pengaruh Strategi Diversifikasi Dan Karakteristik Perusahaan Terhadap Kinerja Perusahaan", JAFFA (Journal of Auditing, Finance, and Forensic Accounting), Vol.02, no.1, pp.13-22.

Scott, W. R. (2015), Financial Accounting Theory, Edisi 7, Toronto: Pearson Canada Inc.

Setionoputri, A., Meiden, C., \& Siagian, D. (2007), "Pengaruh Diversifikasi Korporat Terhadap Excess Value Perusahaan Manufaktur, Perdagangan Grosir Dan Eceran, Serta Properti Dan Real Estate Yang Terdaftar Di BEI Tahun 2005-2007” Bidang Akuntansi Private: Akuntansi Keuangan dan Pasar Modal, pp.1-25.

Satoto, S. S. (2009), "Strategi Diversifikasi Terhadap Kinerja Perusahaan", Jurnal Keuangan dan Perbankan, Vol.13, no.2, pp.280-287.

Spence, M. (2002), "Signaling in Retrospect and the Informational Structure of Markets", American Economic Review, Vol.92, no.3, pp.434-459.

Sumendap, R., Parengkuan, T., \& Maramis, J. B. (2018), “Analisis Perbandingan Kinerja Keuangan Berdasarkan Diversifikasi Segmen Bisnis Pada Industri Manufaktur Yang Go Public Comparative Analysis of Financial Performance Based On Diversification of Business Segments in Manufacturing Industry That Go Public", Jurnal Riset Akuntansi dan Keuangan, Vol.6, no.4, pp.2198-2207.

Wolk, H. I., Dodd, J. L., \& Tearney, M. G. (2003), Accounting Theory: Conceptual Issues in a Political and Economic Environment, Edisi 6, Mason: South-Western College Pub. 